\title{
Growth Parameter and Fecundity of Fringe Scale Sardine (Sardinella fimbriata Cuvier Valenciennes) in Alas Strait, East Lombok, West Nusa Tenggara
}

\author{
Vindy Rilani ${ }^{*}{ }^{*}$, Mulyanto², Daduk Setyohadi \\ ${ }^{1}$ Master Program of Aquaculture, Faculty of Fisheries and Marine Sciences, University of Brawijaya, Malang, Indonesia \\ 2 Faculty of Fisheries and Marine Sciences, University of Brawijaya, Malang, Indonesia
}

\begin{abstract}
Fisheries in the Alas Strait, East Lombok, West Nusa Tenggara is one of important sea area for the activity of fishing, especially small scale fishermen. In addition, the Alas Strait have a good fishery for catching pelagic fish species of Fringe Scale Sardine (Sardinella fimbriata). The aim of this study was to asses the growth parameter and fecundity of Fringe Scale Sardine (S. fimbriata). The research was conducted on August to December 2016, at the Fish Landing Base Tanjung Luar, East Lombok, West Nusa Tenggara. Survey methods and stratification sampling method were used from commercial catch. The relation between weight and length of $S$. fimbriata males and females are the values of $b$ range 2.62750-2.69449 and 2.63959-2.72040, respectively. The growth patterns of male and female fish showed negative allometric growth pattern. The growth parameters of male fish is $L \infty 177.50 \mathrm{~mm} ; \mathrm{K} 0.51 \mathrm{month}^{-1} ; \mathrm{t}_{0}-0.53 \mathrm{month}^{-1}$, while

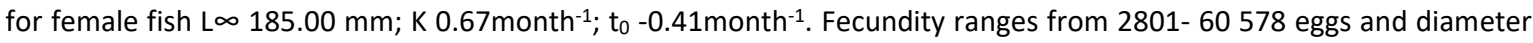
size range of eggs 8-67 $\mu \mathrm{m}$.
\end{abstract}

Keywords: fish growth, fecundity, Sardinella fimbriata.

\section{INTRODUCTION}

Alas Strait, East Lombok, West Nusa Tenggara is known as crucial area for the small scale activity of fishing. Alas Strait also a good fishery spot for catching pelagic fish species such as Fringe Scale Sardine (Sardinella fimbriata), or locally known as Tembang fish. People in Lombok know the fringe scale fish with other local name such as teri ijo and onyok. The fish is mostly utilize for food and livelihoods to the market price of Rp. 8,000 per $\mathrm{kg}$ accompanied by considerable development fisheries [1].

Fish resources are common property and has free rates of utilization. However, the higher exploitation of fish resources continuously followed by uncontrolled utilization, result in the significant decreased on the availability of fish stock in nature [2].

Potential of Tembang fish in the territorial waters of the Alas Strait, related to the future potential and opportunities, the high utilization rate and stock condition which tends to decrease, and the lack of information on the reproductive biology of Fringe scale sardine were feared to disrupt the sustainability of fish resources. Therefore, it is necessary to conduct

\footnotetext{
* Correspondence author:

Vindy Rilani

Email : dyvindy@gmail.com

Address : Faculty of Fisheries and Marine Sciences, University of Brawijaya, Jl. Veteran Malang, 65145
}

anticipation act in the management through parameter information on the growth and reproduction of the fish. This study was aimed to assess the parameter of fish growth and fecundity of the Fringe Scale Sardine ( $S$. fimbriata) in Alas Strait, East Lombok, West Nusa Tenggara.

\section{MATERIALS AND METHODS}

\section{Research Site}

The research was conducted on August to December 2016. Sardinella fimbriata fish collected during the study came from catches of fishermen in the waters of the Alas Strait at Tanjung Luar Fish Landing Base, East Lombok, West Nusa Tenggara (Fig. 1).

\section{Methods of Fish Sampling}

This study used stratification sampling of $S$. fimbriata, collected from a commercial catch. Collected fish were brought to the laboratory and thoroughly cleaned in Reproduction Laboratory analysis at the Faculty of Fisheries and Marine Sciences, University of Brawijaya, Malang.

\section{Analysis of Data \\ Weight and Length of Fish}

Equations for the relation of weight and length of fish almost follow the law of cubic, i.e. Weight of fish is the cubed number of its length. 
However, the relation on the fish was not cubed. The correct equation following the formula [3].

\section{Description:}

$$
\mathrm{W}=\mathrm{aL}^{\mathrm{b}}
$$

$\mathrm{W}=$ weight $(\mathrm{g})$

$\mathrm{L}=$ length $(\mathrm{mm})$, $\mathrm{a}$ and $\mathrm{b}=$ constants

\section{Estimation of Growth Parameter}

Walford plot is one of the simplest methods of predicting the growth parameters $L \infty$ and $K$ parameters used the von Bertalanffy equation with the same interval sampling [3].

\section{Description:}

$$
\mathrm{Lt}=\mathrm{L} \infty\left(1-\mathrm{e}^{\left[-\mathrm{K}\left(\mathrm{t}-\mathrm{t}_{0}\right)\right]}\right)
$$

$L t=$ length of the fish at the age $t$

$L \infty=$ theoretical maximum length (length asymptotic)

$\mathrm{K}=$ coefficient of growth (per unit time)

$t_{0}=$ theoretical age at the time of a length equal to zero

The results of calculations then analyzed further using the method of ELEFAN I (Electronic Length Frequencies Analysis) contained in FISAT II program. FISAT II Program is a method of analysis estimation of fish growth parameter based on the data of length frequency distribution which was obtained [4].

\section{Maturity Stage of Gonads}

Description analysis of maturity gonads based on the visual morphology and histology of gonads sample. The statement method used Tester and Takata, which explained by Effendie [3].

\section{Fecundity}

Egg fecundity is calculated on the maturity condition of gonad III and IV by combined method [3]. The measurement of eggs diameter used light microscope scale $4 \times 0.10 \mu \mathrm{m}^{-1}$ [3].

$$
\begin{aligned}
& \mathbf{F} \quad=\frac{G \times V \times X}{Q} \\
& \text { Description: } \\
& \mathrm{F}=\text { fecundity (eggs) } \\
& \mathrm{G}=\text { total gonad weight }(\mathrm{g}) \\
& \mathrm{V}=\text { dilution volume }(\mathrm{mL}) \\
& \mathrm{X}=\text { egg total in } 10 \mathrm{cc} \\
& \mathrm{Q}=\text { gonad weight example }(\mathrm{g})
\end{aligned}
$$

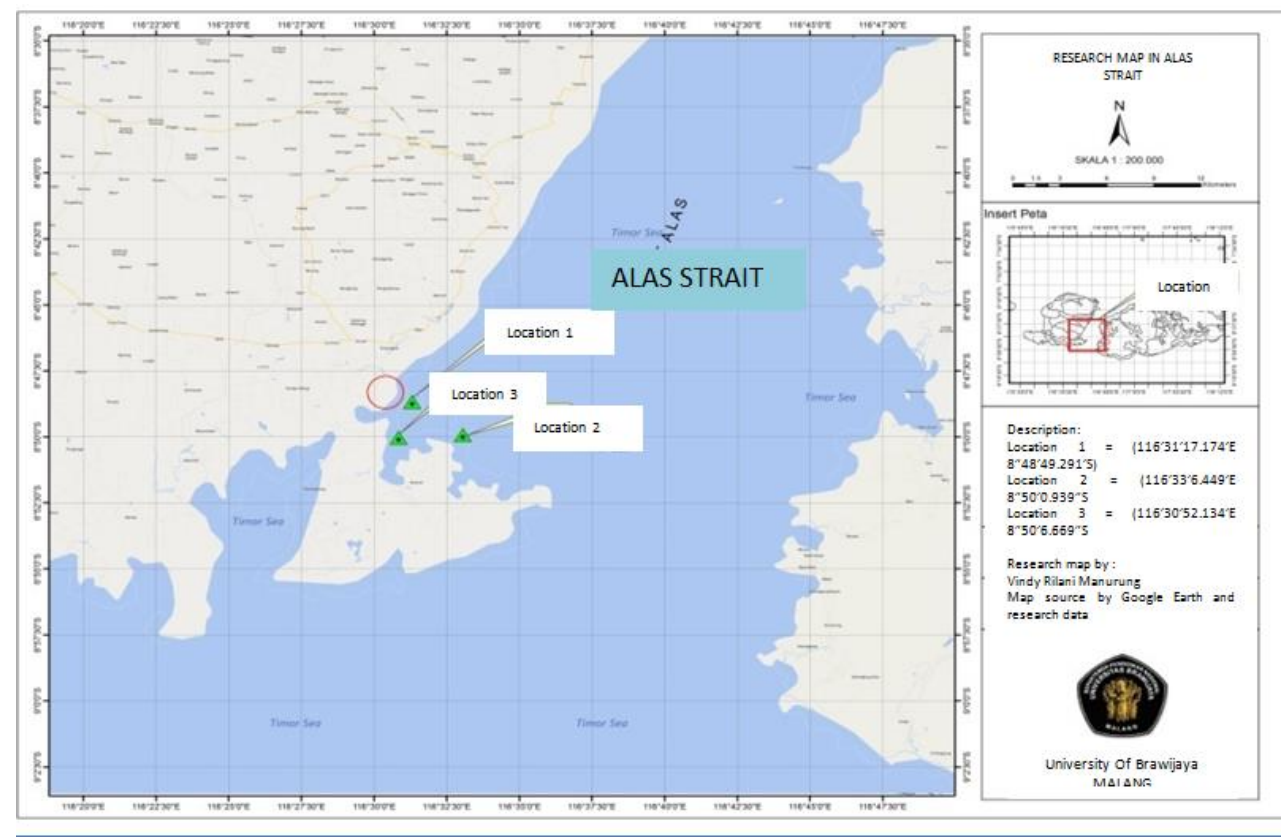

Figure 1. Research Location

\section{RESULT AND DISCUSSION \\ Weight and Length of Fish}

Analysis of relationship between weight and length of fish $S$. fimbriata obtained from 750 fishes compared to the total weight (gram) of fishes (Fig. 2).The relationship between weight and length of fish is 2.63959-2.72040 value $b$ range for males, and females is 2.62750-2.69449 (also value of b). Otherwise, the growth patterns of male and female showed negative allometric growth pattern, indicated that the length $(\mathrm{mm})$ of fish growth faster compared to the increase of weight (g) (Table 1). In the Aegean Sea, Mediterranean, the relationship equation of $S$. fimbriata weight with values range of $b$ is 3.064 
in male and 3.084 for female, with positive values of allometric growth pattern [5].

Other study in the Sunda Strait found $b$ value at 2.834 for males and 2.683 for females, also with negative allometric growth pattern [6]. Sardinella fimbriata fish tend to has different growth patterns to the each different location. This could be to the differences in the condition of the aquatic environment, the size of the fish samples taken and the amount of food [7].
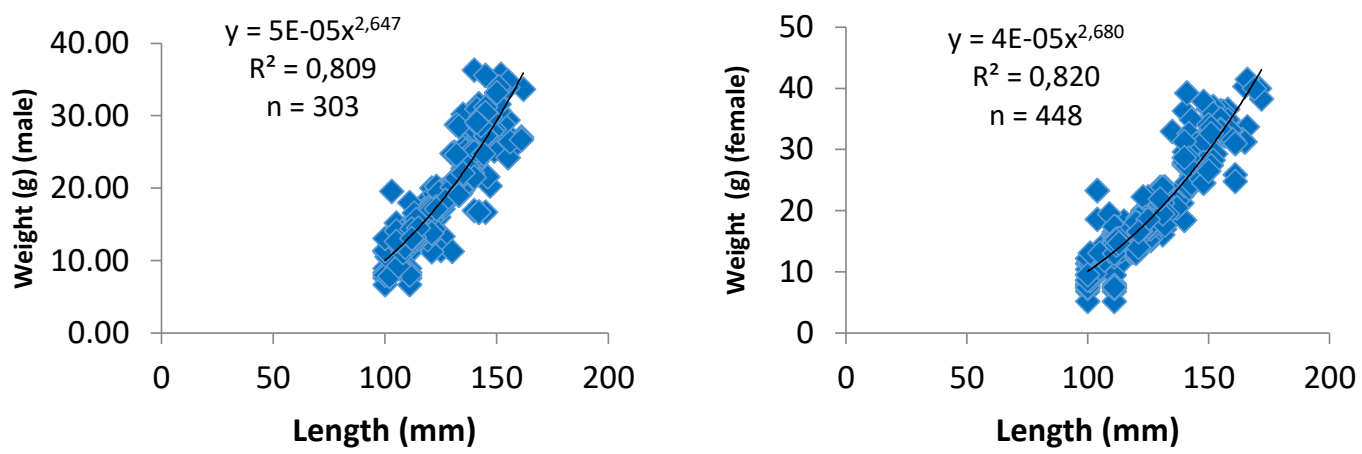

Figure 2. Correlation between Weight and Length of S. fimbriata Male and Females

Table 1.Weight and Length of S. fimbriata

\begin{tabular}{|c|c|c|c|}
\hline Gender & $\mathbf{R}^{2}$ & $\begin{array}{l}\text { Value prediction } \\
\qquad b(\alpha=0.05)\end{array}$ & Growth after test $T(\alpha=0.05)$ \\
\hline Male & 0.80 & $2.63959-2.72040$ & Allometric negative \\
\hline Female & 0.81 & $2.62750-2.69449$ & Allometric negative \\
\hline
\end{tabular}

\section{Estimation of Growth Parameter}

Analysis of fish growth parameter show that female fish growth rate higher than the growth rate of male fish (Table 2). This suggests that the length growth of female fish $(\mathrm{L} \infty(\mathrm{mm}))$ will be faster than male. The faster pace of growth, the fish achieve the asymptotic length faster and will quickly experience death. If the growth coefficient of a species is lower, then the longer time required by the species to achieve the asymptotic length [8].

Table 2. Growth parameter fringe scale fish (S. fimbriata)

\begin{tabular}{cccc}
\hline Gender & $\mathbf{L} \infty \mathbf{( m m})$ & $\mathbf{K}$ (month $\left.^{-1}\right)$ & $\mathbf{t}_{0}$ (month) \\
\hline Male & 177.50 & 0.51 & -0.53 \\
\hline Female & 185.00 & 0.67 & -0.41 \\
\hline
\end{tabular}

\section{Maturity Stage of Gonads}

The observation of gonads morphology and histology can be seen in Figure 3. The proportion of the maturity stage of gonads dominated by observation month of gonad maturity stage I, while the maturity stage of gonads IV are less found. The total amount obtained from 750 fishes, total of male stage IV found is 28 fishes and total stage IV female found is $\mathbf{4 1}$ fishes. We assumed that the spawning season which occurs before August thus certain fish found in stage III and IV that can be used as an indicator of fish spawning in waters. The peak spawning season of S. fimbriata in the waters of Karwar is January and April. While, Sardinella spawning season in the south and west coast of India is August to February with individual spawning only once in a season [9].

Other study found the fish spawning season in the sea of the Indian took place in May-June [10]. Meanwhile in the sea of the Mediterranean in Egypt, spawning of $S$. aurita (family Clupeidae) from the period of June to September, with a peak in late July and early August; when the annual water temperature reaches its maximum [11].

Based on the percentage of stage IV fish, we concluded that the fish spawning season that occurs throughout the year. Differences in fish spawning season caused by the fluctuation of the annual rainy season, geographical location, and condition of the fish [12]. 

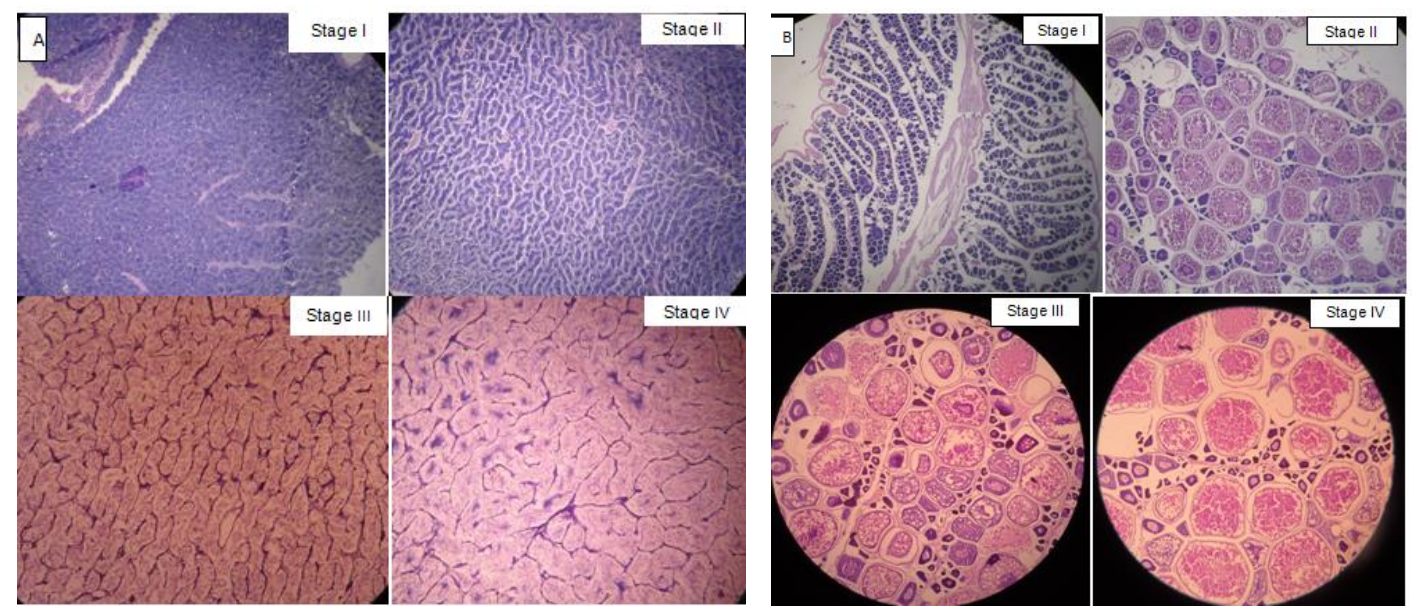

Figure 3. Gonads Histology S. fimbriata, male (a) and females (b)

\section{Fecundity}

The analysis and calculations showed the value of fish fecundity female of stage IV ranges from 2801- 60578 eggs. Previous research in the Indian sea found Sardinella female fecundity from 5500 to 41700 eggs [13]. Other study of $S$. fimbriata fish in the waters of Karwar, India estimated from 14508-25485 fecundity [9]. Diameter size range of fish eggs is 8-67 $\mu \mathrm{m}$ (Fig.4). Type of fish spawning can be seen from the distribution of the diameter of the eggs in the gonad maturity stage IV. Distribution of the highest grade fish eggs diameter is at interval of $38-42 \mu \mathrm{m}$.

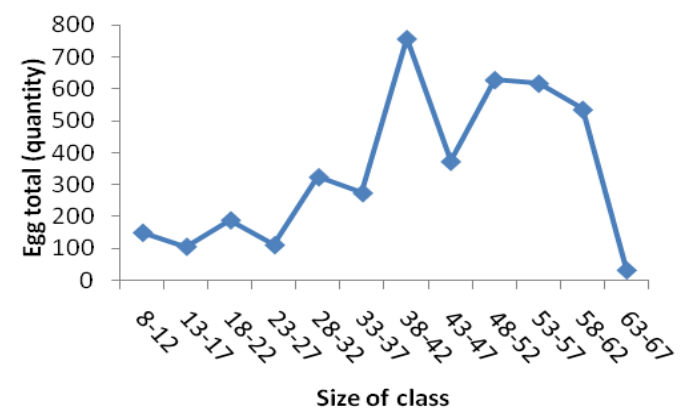

Figure 4. Diameter Size Range of Fish Eggs

These data indicate that this type of fringescale is a partial spawning fish. Essentially, female pelagic fish have fecundity and has a very high spawning periods are often protracted, since all eggs are rarely released in one spawning periode. However, the shortest spawning period is found in small pelagic fish that live in the middle zone, because the optimal conditions for the survival of embryos and larvae tend to depend on the period of the season [14]. The size of the diameter of the eggs is influenced by the amount of food (food supply) on the female fish metabolic processes [15].

\section{CONCLUSION}

The growth pattern of Sardinella fimbriatamale and female fish showed the pattern of negative allometric growth. The value of the growth parameters of male fish is L $\infty 177.50$ $\mathrm{mm}, \mathrm{K} 0.51$ month $^{-1}$, to-0.53 month $^{-1}$, while for female fish $L_{\infty} 185.00 \mathrm{~mm}, \mathrm{~K} 0.67$ month $^{-1}$ and to -0.41 month $^{-1}$. The proportion of the maturity stage of gonads dominated by gonad maturity stage I, while the maturity stage of gonads IV are less. The fish fecundity of femalestage IV ranges from 2801- 60578 eggs with diameter size range of fish eggs is 8-67 $\mu \mathrm{m}$. For further research, we suggest to focus on the biological aspects of fish represent all seasons to represent the time series data, thus the trend of each year can be seen.

\section{REFERENCES}

[1] Personal Communication, 2016. Fish Landing Base Tanjung Luar, East Lombok, West Nusa Tenggara.

[2] Sutisna, D.H. 2007. Model pengembangan perikanan tangkap di Pantai Selatan Provinsi Jawa Barat. PhD Thesis. Graduate School, Bogor Agricultural University. Bogor.

[3] Effendie, M.I. 2002. Biologi perikanan. Yayasan Pustaka Nusatama. Yogyakarta.

[4] Udupa, K.S. 1986. Statistical method of estimating the size at first maturity in fishes. Fishbyte. 8-10.

[5] Tsikliras, A.C., E.T. Koutrakis, K.I. Stergiou. 2005. Age and growth of round Sardinella (Sardinella aurita) in the Northeastern Mediterranean. Sci. Mar. 69(2). 231-240. 
[6] Simarmata, R. 2014. Pengelolaan sumber daya Ikan Tembang (Sardinella fimbriata) di Perairan Selat Sunda. Master Thesis. Graduate School, Bogor Agricultural University. Bogor.

[7] Athukoorala, A.A.S.H., K.H.K. Bandaranayaka, S.S.K. Haputhantri. 2015. A study on some aspect of reproductive biology and populaton characteristics of Amblygaster sirm in the west coast of Sri Lanka. Int. J. Fish. Aquat. Stud. 2(4). 41-45.

[8] Sparre, P., S.C. Venema 1999. Introduksi pengkajian stok ikan tropis. Research Center and Debvelopment of Fisheries. Jakarta.

[9] Kudale, R.G., J.L. Rathod. 2015. Maturation and spawning in the fringe scale sardine, Sardinella fimbriata (Cuvier and Valenciennes, 1847) from Karwar waters, Uttar Kannada District, Karnataka. Int. J. Fish. Aquat. Stud. 4(2). 96-99.

[10] Ghosh, M.V., H. Rao, S. Sumithrudu, P. Rohit, G. Maheswarudu. 2013. Reproductive biology and population characteristics of Sardinella gibbosa and Sardinella fimbriata from northwest Bay of Bengal. Indian J. Geo-Mar. Sci. 42(6). 758-769.

[11] El-Rashidy, H.H.H. 1987. Icthyoplankton of the south eastern Mediterranean Sea off the Egyptian Coast. Master Thesis. Faculty of Science, Alexandria University. Egypt.

[12] Sulistiono, M.I. Ismail, Y. Ernawati. 2011. Tingkat kematangan gonad ikan Tembang (Clupea platygaster) di Perairan Ujung Pangkah, Gresik, Jawa Timur. Biota. 16(1). 26-38.

[13] Bennet, P.S. 1967. Some observations on the fishery and biology of Sardinella fimbriata (VAL.) At Vizhingam. Central Marine Fisheries Research Institute, Mandapam C. 14(1). 2.

[14] Moyle, P.B., C. Joseph Jr. 2004. Fishes: An Introduction to ichthyology, $5^{\text {th }}$ Ed. PrinceHall. Inc. New Jersey.

[15] Nikolsky, G.V. 1963. The Ecology of Fishes. Academy Press. New York. 